\title{
Phytochemical screening and antimicrobial activity of selected medicinal plant species
}

Sajjad Ali1 ${ }^{*}$, Kashif Ali ${ }^{2}$, Zahid Hussain ${ }^{3}$, Muhammad Saleem Khan ${ }^{2}$, Wisal Muhammad Khan ${ }^{2}$, Sher Wali ${ }^{2}$ and Muhammad Shuaib ${ }^{4}$

1. Department of Botany, Bacha Khan University Charsadda, KP-Pakistan

2. Department of Botany, Islamia College Peshawar, KP-Pakistan

3. Department of Agronomy, Bacha Khan University Charsadda, KP-Pakistan

4. School of Ecology and Environmental Science, Yunnan University-China

*Corresponding author's email: sajjad_ali00@yahoo.com

Citation

Sajjad Ali, Kashif Ali, Zahid Hussain, Muhammad Saleem Khan, Wisal Muhammad Khan, Sher Wali and Muhammad Shuaib. Phytochemical screening and antimicrobial activity of selected medicinal plant species. Pure and Applied Biology. Vol. 6, Issue 2, pp418-425. http://dx.doi.org/10.19045/bspab.2017.60042

\begin{tabular}{llll}
\hline \hline Received: $15 / 12 / 2016$ & Revised: 06/03/2017 & Accepted: 14/03/2017 & Online First: 19/03/2017 \\
\hline \hline
\end{tabular}

\section{Abstract}

Phytochemicals are essential compounds, utilized worldwide for curing of various human disorders. The present study comprised of 12 different medicinal plant species i.e. Withania coagulans, W. somnifera, Cannabis sativa, Medicago sativa, Achyranthes aspera, Convolvulus arvensis, Solanum nigrum, Mentha longifolia, Mentha spicata, Tagetes erecta, Fagonia cretica and Acacia nilotica. These species were used by the local inhabitants for treating various aliments. Methanolic extract of leaves of these plant species were investigated for cardiac glycosides, alkaloids, tannins, saponins, flavonoids, terpenoids, anthraquinones and reducing sugars. Among the reported medicinal plant species, Leaves of Acacia nilotica and Withania somnifera were tested for antibacterial activity which showed significant activity against Bacillus subtilis, Escherichia coli, Staphylococcus aureus and Pseudomonas fluorescens.

Keywords: Medicinal plants; Phytochemical screening; Antimicrobial activity

\section{Introduction}

There are some diseases in the world which cause death, almost of 40,000 people. Disease like diarrhea cause huge mortality among childrens [1]. Bacteria like Escherichia coli, Salmonela spp. and Staphylococcus aureus are most common species which are pathogen on children [2]. In recent years drug resistance to human pathogenic bacteria has been commonly reported from all over the world [3]. A large number of drugs are obtained from plant and used for many serious disorders [4]. In East
Asia, many plants are considered to have significants medicinal features i-e antiinflammatory, anti-bacterial and analgesic funcation because they contain a large variety of phytochemical i-emoniterpenoids, sesquiterpenoids, and curcuminoids $[5,6]$. Withania somnifera (family Solanaceae) is a medicinal plant utilized for large number of diseases. Every part of these plant have a big sources of many chemicals and widely used for cureing ulcers, fever, cough, dyspnoea, dropsy, rheumatism, toxicosis and leucoderma [7]. Acacia nilotica. Is very 
common small tree it also known as kikar belongings to the family Mimosaceae [8]. Acacia nilotica is consider to be antidysentric and antispasmodic .The pod and leaves are also utilized for medicinal purpose i-e diarrhea. Acacia nilotica part extract has been shown to exhibit antibacterial, antiplatelet and anti-oxidant. [9]. The stem bark of Acacia nilotica is well-known for its diuretic properties [9] These medicinal plants are important because of their uses for curing disorder and for healing as well [10]. These plants are important because of their phytochemical and large number of significant features. There are many other reports which show importance of these plants for their antimicrobial activity and phytochemicals like [10-12]. In Pakistan 6000 plant species were present In which about 180 plant were used for medicinal. The phytochemicals are two type including primary phytochemical which have not such a strong action in medicine while the secondary phytochemical are worldwide used for many ailments, the most important secondary phytochemical are Alkaloids, Terpenoids [12]. Secondary phytochemicals are compounds which show no function to be incorporated in primary metabolism, they act as accessory role. Rather than medicinal uses these phytochemicals are used by the plant for their defense as well [12].

Terpenoids play a vital role in most pharmacological work and activities, medicinally it play an important role in anticancer, anti-malarial and anti-fever as well [3]. Alkaloids are also important secondary chemical which play a vital role as anesthetic agent. Alkaloids also create variation in physiology [13]. Phenol and its compound are distributed in many plants, phenolic compound are used for the treatment of many disorder and also due to its toxic action prevent the growth of many pathogens [14]. Flavonoids, sterol, and saponins are essential secondary chemical present in above 85 families, due to their multipurpose and specific chemistry they are used for the treatment of many disorder [15]. All these phytochemicals give a strong immunity in the form of resistance against many insects and herbivores as well [16]. In this universe about 4,44000 flowering plant species are present, in which 40000 plant species are utilized due its phytochemical importance.

\section{Materials and methods Collection of plants}

For the collection of plant species field survey were occurred throughout the research site during 2014. The listed plant species (Table 1) were collected and then dry. These plant species were identified at department of Botany Islamia College University, Peshawar.

\section{Materials extract from plants}

The dried material were obtained from these plant by keeping them at room temperature 28 degree celcius for 18 days, they were grinded into fine powder. Extract of ethanol were made through soaking $70 \mathrm{~g}$ of powder from plant specimen in $1.3 \mathrm{~L}$ ethanol. For making a viable extract of ethanol 42 hours were required at room temprature.

\section{Extraction of solvent}

The dried leave of two plants i.e Withania somnifera and Acacia nilotica were washed and the slected plant material were dried. The parts of these plants were kept in oven at $40{ }^{\circ} \mathrm{C}$ then changed into powdered with mortar and pestle. 80 grams of each parts of plant and 200 grams $\mathrm{ml}$ of methanol were kept in mortar and with the help of pestle it grind up .this extract were placed at room temperature for 30 hours. This extract where filter through filter paper and dried at temperature below $48^{\circ} \mathrm{C}$ for methanol removal to obtain the dense extract and then they were kept in sterile bottles under refrigerated conditions until use. 


\section{Anti-bacterial testing}

Antibacterial activity was measured using agar dilution technique. Briefly, the methanol extracts were dissolved in dimethyl sulfoxide (DMSO, Merck) and serially diluted in molten Mueller Hinton Agar (MHA, Sigma) in petridishes (100 $\mathrm{mm} \times 15 \mathrm{~mm})$ to obtain final concentrations: $100,50,25$ and $12.5 \mu \mathrm{g} / \mathrm{ml}$. The solvent did not exceed $1 \%$ concentration and did not affect the growth of the organisms. All bacterial strains were grown in Mueller Hinton Broth (MHB, Sigma) for $4 \mathrm{~h}$ at $37^{\circ} \mathrm{C}$. Bacterial suspensions with 0.5 McFarland standard turbidity, which is equivalent to $108 \mathrm{cfu} / \mathrm{ml}$ were prepared by dilution with Mueller Hinton broth. The diluted inoculum was added to a Steer's replicator calibrated and incubated for $24 \mathrm{~h}$ at $37{ }^{\circ} \mathrm{C}$. After incubation, all dishes were observed for microbial inhibition by the disc diffusion method (Table 2).

\section{Rotary Evaporator}

By using rotary evaporator the extract become concentrated. The solutions were also passed through filter paper to make it impurities free and the analyses of phytochemicals are occurred by some procedures which are standrad.

\section{Cardic glycosides test}

Cardic glycosides test needs chemical like Ferric chloride, glacial acetic acid and distal water as well. Extract of $0.7 \mathrm{gm}$ diluted through $10 \mathrm{ml}$ of water, $3 \mathrm{ml}$ of glacial acetic acid and also few drop of feric chloride were also included. Specific colors were responsible for sugar indicator and light brownish spots were indicative feature of deoxysugar, also some green spots were present as well.

\section{Flavonoids test}

For the determination of flavonoids dilute amonia was introduced. $3 \mathrm{ml}$ of dilute amonia were added to extract, sulphiric acid were also used. By the appearance of yellow colour showed that presence of flavonoids $[17,18]$.

\section{Alkaloids test}

For the indication of phytochemical like alkaloids, $0.6 \mathrm{~g}$ of extract were mixed to $7 \mathrm{ml}$ acidified alchole, after mixing they were boiled and then their filteration occurred. $4 \mathrm{ml}$ after filteration was mixed with $2 \mathrm{ml}$ of dilute amonia, $3 \mathrm{ml}$ chlorofome were introduced and then mixed, after mixing gently the chlorofome appearance occurred in the form of layer with $6 \mathrm{ml}$ of acitic acid. At last the formation of brownish red precipate appear which clearly indicate alkaloids $[19,20]$.

\section{Terpenoid test}

Take $0.3 \mathrm{~g}$ of the sample extract and add to $2 \mathrm{ml}$ of chloroform. A small amount of concentrated $\mathrm{H}_{2} \mathrm{SO}_{4}(2 \mathrm{ml})$ were introduced for obtaining the phytochemicals. The appearance of reddish brown colour showed the presence of terpenoids.

\section{Tannins test}

Boiled extract about $0.3 \mathrm{~g}$ in $7 \mathrm{ml}$ of water were mixed in a test tube and then filter. Ferric chloride was also add about few drops $0.2 \%$ after addition blue black or brownish green colour occurred [19, 20$]$.

\section{Anthraquinones test}

Boiled extract about $0.3 \mathrm{~g}$ were taken and mixed with $8 \mathrm{ml}$ of sulphuric acid after mixing then filtered. Mixed $4 \mathrm{ml}$ of chloroform with filtered and then shaked a layer of chloroform were formed which was pipette into test tube at last $2 \mathrm{ml}$ of ammonia were add and wait for colouration.

\section{Reducing sugar test}

Take $0.3 \mathrm{~g}$ of sample and add $7 \mathrm{ml}$ of water. This mixture was add to boiling fehling's solution after reaction colour was observed.

\section{Saponins test}

Test for saponins required oil of olive, $0.4 \mathrm{~g}$ of extract was taken and then mixed with $7 \mathrm{ml}$ of water and make a solution, this solution was mixed with a few drop of olive oil. Observed the colour [21, 22]. 
Test sample preparation for antimicrobial test

For the antimicrobial tests, ethanolic extracts were diluted in dimethylsulfoxide (DMSO): methanol (1/1: v/v) solvent to a concentration of $20 \mathrm{mg} / \mathrm{ml}$.

Table 1. List of medicinal plant species and their part used for phytochemical analysis

\begin{tabular}{|l|l|c|c|}
\hline S. No & Plant Species & Local name & Part used \\
\hline 1 & Acacia nilotica & Kikar & Leaves \\
\hline 2 & Acyranthus aspera & Baikand & Leaves \\
\hline 3 & Cannabis sativa & Bhang & Leaves \\
\hline 4 & Convolvulus arvensis & Perwatai & Leaves \\
\hline 5 & Fagonia cretica & Azgakay & Leaves \\
\hline 6 & Medicago sativa & Alfa alfa & Leaves \\
\hline 7 & Mentha spicata & Podina & Leaves \\
\hline 8 & Mentha longifolia & Weenalay & Leaves \\
\hline 9 & Solanum nigrum & Kachmacho & Leaves \\
\hline 10 & Tagetes erecta & - & Leaves \\
\hline 11 & Withania coagulans & Ashtoshbooti & Leaves \\
\hline 12 & Withania somnifera & Ashwagandha & Leaves \\
\hline
\end{tabular}

Table 2. Antibacterial activity of some medicinal plant methanol extracts (50 $\mu \mathrm{g} \mathrm{mIG1)} \mathrm{and}$ fungicide (60 $\mu \mathrm{g} \mathrm{mlG1)} \mathrm{against} \mathrm{fungal} \mathrm{species} \mathrm{tested} \mathrm{by} \mathrm{disc} \mathrm{diffusion} \mathrm{Zone} \mathrm{of} \mathrm{inhibition}$ (mm)

\begin{tabular}{|l|c|c|}
\hline Botanical species & Acacia nilotica & Withania somnifera \\
\hline Bacteria species spp & Bark & Leaves \\
\hline Bacillus subtilis & $16 \pm 0.34$ & $10 \pm 0.32$ \\
\hline Escherchia coli & $13 \pm 0.20$ & $8 \pm 0.33$ \\
\hline Stphaylocuccus aureus & $11 \pm 0.13$ & $6 \pm 0.01$ \\
\hline Pseudomonas fluorescence & $9 \pm 0.13$ & $4 \pm 0.01$ \\
\hline
\end{tabular}

\section{Results and discussion}

The present work showed presence of phytochemicals which are considered as an active medicinal constituent. This work presented 12 different plants which are medicinally important because of the presence of such important phytochemicals as show in (Table $3 \&$ Figure 1). The result also showed that two medicinal plant Withania sommifera and Accacia nilotica are utilized for antimicrobial activity. These plant also contain important medicinal phytochemical, include such as terpenoids, reducing sugar, alkaloid etc were found in the test species sample. [23] also reported the phytochemical anaylasis of the arieal parts of various plant i-e Flavonids, glycoside alkaloids same is true in the present rearseach. . Withania coagulans contain all the important phytochemical except the reducing sugar, cannabis sativa, Mentha spicata, Mentha longifolia, Achyranthus asper, Medicago sativa, Tagetis erecta, Solanum nigrum, Convolvulus arvensis, Withania sommifera, the specimen of these plant were showed the presence of all the phytochemical. The test of the Fagonia cretica showed the presences of terpenoids and flavonoids, while the tested part of the Acacia nilotica show the presences of reducing sugar, terpenoids and flavonoids. [24] also described various 
medicinal flora which were used due to presences of phytochemicals which are in line with present research.

The presence and absence of medicinal phytochemical in plant are related to various activity in plants such as physiological and biosynthetic reaction. Ecological effect should not be neglected like temperature, soil nature, availability of water and soil fertility, these factor also play a vital role in plant activity. Accacia nilotica and Withania somminfera these two medicinal plant extrat are used for inhibition the growth of bacteria both of ths plant showed a significant result against Bacillus subtilis, Escherchia coli, Stphaylocuccus aureus and Pseudomonas fluorescence. [25]. [26] also reported evaluation of antibacterial properties of medicinal plant which were utilized in making many medicines that's what the present report show. [26-28] also reported the antimicrobial activity of of these flora which were utilized in making medicine same is true in the present finding. Withania somminfera is another important medicinal plant species containing many important alkaloids which are used in medicine [29]. $[30,31]$ also reported Acacia nilotica and Withania somnifera showed significant antibacterial activity against Bacillus subtilis, Escherchia coli, stphaylocuccus aureus and pseudomonas fluorescence. Same is true in the present finding.

Table 3. Below shows phytochemical analysis of different medicinal plants

\begin{tabular}{|c|c|c|c|c|c|c|c|c|}
\hline Plant specie & $\begin{array}{l}\text { Reducing } \\
\text { sugar }\end{array}$ & Anthraquinone & Terpenoids & Flavonoids & Saponins & Tannin & Alkaloids & Cardicglycocids \\
\hline Acacia nilotica & + & & + & + & & & & \\
\hline Achyranthus asper & + & + & + & + & + & + & + & + \\
\hline Cannabis sativa & _- & + & + & + & + & + & + & + \\
\hline Convolvulus arvensis & + & + & + & + & + & + & + & + \\
\hline Fagonia cretica & - & - & + & + & - & - & - & - \\
\hline Medicago sativa & + & + & + & + & + & + & + & + \\
\hline Mentha longifolia & + & + & + & + & + & + & + & + \\
\hline Mentha spicata & + & + & + & + & + & - & + & + \\
\hline Solanum nigrum & + & + & + & + & + & + & + & + \\
\hline Tagetis erecta & + & - & + & + & + & + & + & + \\
\hline Withania somminfera & + & + & + & + & + & + & + & + \\
\hline Withania coagulans & + & + & + & + & + & + & + & + \\
\hline
\end{tabular}




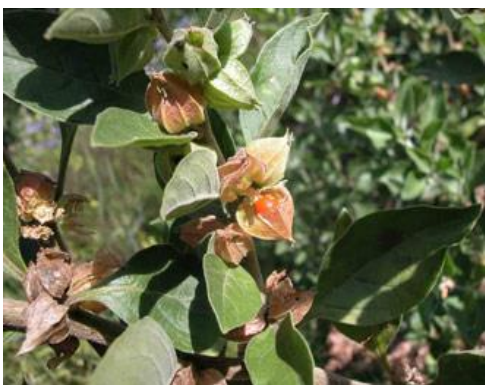

Withania sommifera

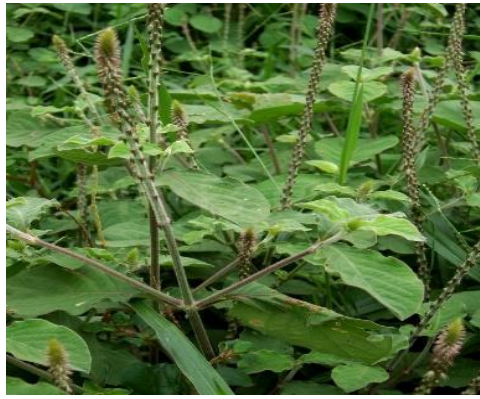

Achyranthus aspera

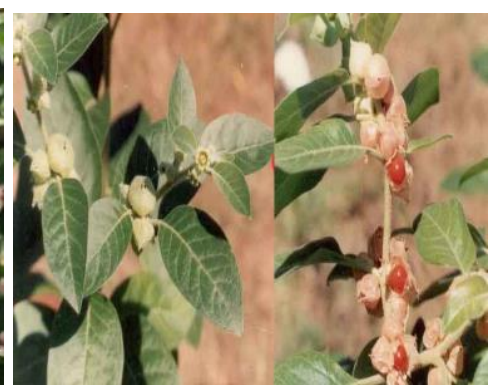

Withania coagulens

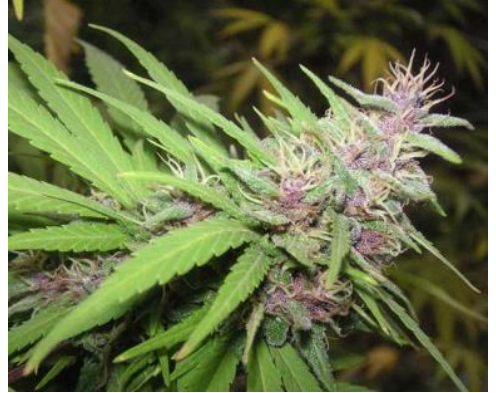

Cannabis sativa

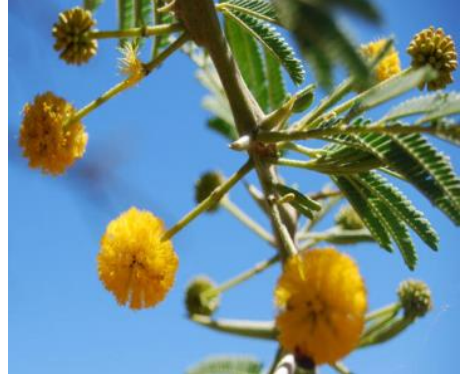

Acacia nilotica

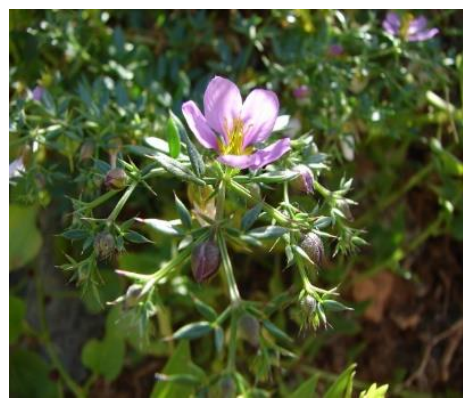

Fagonia cretica

Figure 1. Represent important plant species

\section{Conclusion}

The plant which are selected in this report provide important and medicinal secondary metabolites. These plants are big source of secondary metabolites including, Alkaloids, reducing sugar, anthraquinone, terpenoids, flavonoids, saponins, tannin, and cardic glycocides. These secondary metabolites are useful in preventing different diseases. These phytochemical are used for many ailments like as antidiuretic, pain killer, anticancer, anti-viral, anti-fungal and antibacterial as well. Screenings of the phytochemical constituent are very important for the synthesis of new medicine and drugs.

\section{Authors' contributions}

Conceived and designed the experiments: S Ali, K Ali \& Z Hussain, Performed the experiments: MS Khan, WM Khan, Analyzed the data: S Wali \& M Shuaib, Contributed reagents/ materials/ analysis tools: S Ali and K Ali, Wrote the paper: S Ali.

\section{References}

1. Araujo CAC \& Leon LL (2001). Biological activities of Curcuma longa L. Mem Inst Oswaldo Cruz 96(5): 723728.

2. Bonjor S (2004). Evaluation of antibacterial properties of some medicnal plant used in Iran. $J$ Ethnopharmacol 44: 35-40.

3. Briskin DP (2000). Medicinal plants and phytomedicines. Linking plant biochemistry and physiology to human health. Plant Physiol 124(2): 507-514.

4. Kunin CM (1993). J Internal Medicine 118 (7): pp. 557-561.

5. Choudhary MI, Dure-e- Shawar, Perveen Z, Jabbar A, Ali I \& Rehman A (1995). Antifungal steroidal lactones from Withiana coagulance. Phytochem 440 (4): 1243-1246. 
6. De, boer HJ, Kool A, Broberg A, Mziray WR, Hedberg I \& Levenfors JJ (2005). Antifungal, antibacterial activity of some herbal remidies from Tanzania. $J$ Pharmacol 96: 461-469.

7. El Shanawany MA (1996). Medicinal plant used in Saudi traditional medicine, King Abel aziz city for Science and Technology, Riyadh. 144.

8. Elesabetsky E (1991). Sociopolitical, economical and ethical issues in medicinal plant rsearch. $J$ Ethnopharmcol 32(1-3): 235-239.

9. Fang JY, Hung CF, Chiu HC, Wang JJ \& Chan TF (2003). J Pharm Pharmacol 55: 1175 .

10. Gupta S, Walia A \& Malan R (2011). Phytochemistry and pharmacology of Cedrusdeodera: An overview. J Pharm Sci and Res 2(8): 2010-2020.

11. Harborne JB (1973). Phytochemical methods, London Chapman and Hall, Ltd, 49-88 pp.

12. Heinrich M, Ankli A, Frei B, Weimann C \& Sticher O (1998). Medicinal plants in Mexico: Healers' consensus and cultural importance. Soc Sci and Med 47(11): 1859-1871.

13. Islam B, Khan SN, Haque I, Alam M, Mushfiq M \& Khan AU (2008). Novel anti adherence activity of Mulberry Leaves: inhibiation of streptococcus mutus biofilim by 1deoxynojirmycin isolated from Moras alba. J Antimicrob. Chemother 62(4): 751-757.

14. Kiran B \& Bargali SS (2009). Acacia nilotica: a multipurpose leguminous plant Nat sci 7(4): 11-19.

15. Marks S \& Clay K (1996). Physiological responses of Festuca arundinacea to fungal endophyte infection. New Phytologist 133(4): 727-733.

16. Maslin BR, Miller JT \& Seigler DS (2003). J Systematic Botany 16(1): 118.
17. Mattila P \& Hellström J (2007). Phenolic acids in potatoes, vegetables, and some of their products. J Food Compos Anal 20: 152-60.

18. Mehmood R (2011). Phytochemical Investigation of Medicinally Important Croton Sparsiflorus and Ziziphora Tenuior Plants (Doctoral dissertation, University of Karachi).

19. Mulligen ME, Kauffman CA \& Yu VL (1993). American Journal of medicine 94: 313-28.

20. Oakenfull DG (1986). Aggregation of bile acids and saponins in aqueous solution. Austr J Chem (39): 16711683.

21. Piddock KJV \& Wise R (1989). Journal of Antimicrobial chemotherapy 23: 475-83.

22. Prusti A, Mishra SR, Sahoo S \& Mishra SK (2008). Antibecterial activity of some Indian medicinal plants. Ethnobot Leafl 12: 227-230.

23. Ramya Krishna P S, Bhaduri Lavanya, Pulla Sireesha, Nagarjuna S \& Padmanabha Y (2011). Reddy Der Pharmacia Sinica 2 (6): 17-22.

24. Rattan RS (2010). Mechanism of action of insecticidal secondary metabolites of plant origin. Crop prot 29(9): 913920.

25. Sharma G, Prakash D, Gupta C, Prakash D \& Sharma G (2014). Phytochemicals of nutraceutical importance: do they defend against diseases. Phytochemicals of Nutraceutical Importance 1.

26. Singh M, Chaudhry MA, Yadava JNS \& Sanyal SC (1992). The spectrum of antibiotic resistance in human and veterinary isolates of Escherichia coli collected from 1984-86 in Northern India. Journal of antimicrobial chemotherapy 29(2): 159-168.

27. Tang W \& Eisenbrand G (1992). Chinese Drugs of Plant Origin; 
Springer-Verlag: Berlin and Heidelberg, Germany pp 401-415.

28. Tyler V (1994). Phytomedicines in

Western Europe: their potential impact on herbal medicine in the United States Herbalgram 30: 24-30.

29. U Devi (1996). Ind J Pharm Sci 34: 927932.

30. Williamson G \& Manach C (2005). Bioavailability and bioefficacy of polyphenols in humans. II. Review of 93 intervention studies. Am J Clin Nutr 81(Suppl 1): S 243-55.

31. Zhang YW, Due DQ, Zhang L, Chen YJ \& Yao XS (2001). Effects of Ginsenosides from Panax ginseng on cell-to-cell communication function mediated by gap junctions. Plants Med 67: 417-422. 